\title{
Business Ethics: Four Spheres of Executive Responsibility
}

Joseph L. Badaracco, Jr.

n The Functions of the Executive, his landmark book on
managers and organizations, Chester Barnard wrote: "It
seems to me inevitable that the struggle to maintain cooperation among men should as surely destroy some men morally as battle destroys some physically." This is a grim observation. It flies in the face of our widespread celebration of business leadership, entrepreneurial achievement, and the triumphal march of capitalism into Asia and now Eastern Europe. Barnard's view also seem unrealistic. Management life is surely not, after all, a series of anguishing moral dilemmas. And when ethical issues do arise, the right answer, morally and legally, is often clear. The typical challenge is finding practical ways to do the right thing, not discerning what is right. The investment bankers who met in dark garages to exchange inside information for suitcases of cash were not struggling on the horn of moral dilemmas but were breaking the law and violating their clients' trust.

Yet in other cases, the central challenge is deciding what is right. In 1988, for example, the executives of Roussel UCLAF, a French pharmaceutical company, had to decide whether to market a new drug called RU 486. Early tests had shown that the drug was 90 to $95 \%$ effective in causing a miscarriage during the first five weeks of a pregnancy. A scientific and medical breakthrough, RU 486 was an alternative to surgical abortions, and its creators believed it could ultimately help hundreds of thousands of women avoid injury and death from botched abortions. As researchers and business managers, many Roussel UCLAF executives had been personally committed to developing RU 486. They faced the question, however, of whether to introduce the drug and how to do so. Protests against Roussel and debates within the company were already diverting a great deal of management time and sapping employee morale. Some of the countries that 
faced severe population problems and wanted access to RU 486-such as China-did not have the medical infrastructure to use the drug safely. Antiabortion groups were threatening an international boycott of the products made by Roussel UCLAF and Hoechst, the German chemical giant that was Roussel UCLAF's largest shareholder. Indeed, the costs of the boycott seemed likely to outstrip the profits from selling RU 486. Moreover, Hoechst's corporate credo emphasized support for life, a reaction to its collaboration with the Nazi death camps during the 1940s.

What were the moral responsibilities of Roussel's executives? How should they have balanced their ethical obligations to the company's shareholders, to their employees, to the women who might use RU 486, and to the medical, and scientific, governmental, and political groups their decisions would effect? What did they owe to their own consciences? In such situations, executives face morally treacherous problems. These are not issues of right versus wrong; they involve conflicts of right versus right, of responsibility versus responsibility. In such cases, managers cannot avoid getting their hands dirty: in meeting some responsibilities, they will fail to meet others, and so they face the anguishing struggle that Barnard described.

The problem of dirty hands is the lot of men and women with power and complex responsibilities. In a play by Jean-Paul Sartre, a young idealist accuses a veteran Communist leader of having sold out to the Nazi occupation. The older man replies:

\footnotetext{
How you cling to your purity, young man! How afraid you are to soil your hands! All right, stay pure! What good will it do? Why did you join us? Purity is an idea for a yogi or a monk. . . . To do nothing, to remain motionless, arms at your sides, wearing kid gloves. Well I have dirty hands. Right up to the elbows. I've plunged them in filth and blood. But what do you hope? Do you think you can govern innocently? $?^{2}$
}

Yet hard moral choices are at times the inescapable lot of men and women in positions of power. How do you fire a friend, someone you have worked with for years? When is it right to violate an employee's privacysomeone with a drinking problem, for example - to get him help he badly needs? Can you have a clear conscience when your company's product will be misused by some customers and hurt innocent people? When can an executive wreak havoc on a workforce and a local community by moving an operation to a low-cost, overseas site? Is it sometimes right to pay a bribe to win a contract and protect jobs?

Some people believe there are fundamentally simple approaches to such situations: let the market decide, search one's heart and be true to one's values, do what is best for the shareholders, take care of the people in the company "family," do what is right for all of a company's stakeholders. These ways of resolving the moral dilemmas of management are beguilingly clear, simple, praiseworthy — and misleading. The search for a grand, 
unifying principle of management morality leads to frustration and often cynicism. The moral dilemmas of management are, at bottom, clashes among different, conflicting moralities, among very different spheres of responsibility. Each sphere is, in many ways, a nearly complete moral universe-its own world of commitments, human relationships, strong duties, norms of behavior, personal aspirations, and choices that bring happiness and suffering to others. ${ }^{3}$ When the claims of these different spheres of commitment pull in different directions, managers face the hazards of which Chester Barnard warned.

\section{Four Spheres of Morality}

The Commitments of Private Life-The first of these moral worlds is the sphere of private life. In part, this realm consists of duties and obligations which are usually stated as abstract, universal principles: tell the truth, keep promises, and avoid injuring others. Individuals disagree about the origins of these duties and the priorities among them, but most people believe that certain fairly clear obligations are binding on everyone. Such principles, however, offer only an abstract, attenuated view - a philosopher's x-rayof the complex morality of individuals' commitments, ideals, and aspirations.

Consider, for example, the case of a young woman who worked as an associate at a New York investment banking firm. She had contributed significantly to a successful assignment, and the client invited the project team to a celebratory luncheon. The young woman was eager to attend, but the luncheon would be held at a small men's club that required women to enter through a side door. As she struggled with this issue, the young woman did not find herself consulting a universal, prioritized list of abstract, ethical duties. She did spend a great deal of time thinking about her family, her experiences in college, her grandmother's decision not to pursue a career with an established law firm because she would have to learn typing and shorthand to get the job, the experiences of other women at her investment bank, and about her hopes for her career.

In short, her "analysis" was refracted through the personal realities of her life and past experience. Moreover, her decision was not simply a choice but an act of self-definition or self-creation: it would partially define the person she would become, someone who had gone through the side door or someone who had done something else. The poet Adrienne Rich observed that "the story of our life becomes our life," and this young woman was about to write-or live out—an important chapter of her personal narrative.

There was no single, universal, "right" decision in this case. The morality of private life differs from person to person, reflecting factors that are individual and often highly particular. Some people are deeply committed to their families, others to their work, or political reform, or strong 
friendships. For many, the sphere of private morality is suffused with religious belief, while others find ideals and aspirations elsewhere-in their parents' example, in philosophy, literature, the lives of people they admire, or convictions born of their own lives and reflection. Personal morality is usually embedded in the unexamined norms and assumptions, the slowly evolving commitments and responsibilities, and the enveloping ways of life of families, friends, and communities.

Much of the morality of private life is implicit and intuitive, and it appears clearest in retrospect, in the patterns underlying one's past actions. Few people have the skills and the inclinations-so highly prized in academia - to state their implicit morality in clear, precise, systematic terms. For some people, rational articulation is a betrayal, a denial of Pascal's observation that the heart has its reasons that reason does not know. Individuals often do not fully understand how or why they made a particular decision. After long reflection, something simply seems right.

Integrity and character play important roles in the morality of private life. From time to time, most people wonder about questions that ancient philosophers first articulated: What distinguishes a good person from a bad one? What ways of living, what guidelines, what virtues make for a good person and a good life? What do I want my life to add up to? What abiding aspirations and commitments will give my life purpose and a sense of wholeness, coherence, and integrity? In the Western world, such questions have defined the morality of private life ever since Socrates, Plato, and Aristotle asked them 2500 years ago.

This sphere of morality seems to be primary, to be morality in its truest and deepest sense. It seems clear, after all, that people are first and foremost individual moral agents and only later take on social roles as executives, attorneys, or physicians. But this is not the whole story. The men and women who become business executives, like others who hold positions of power in society, shoulder the weight of other moral responsibilities. The British historian R.H. Tawney wrote: "To argue, in the manner of Machiavelli, that there is one rule for business and another for private life, is to open the door to an orgy of unscrupulousness before which the mind recoils. To argue that there is no difference at all is to lay down a principle which few men who have faced the difficulty in practice will be prepared to endorse." ${ }^{4}$ Like Chester Barnard, Tawney acknowledges a struggle: between the "rule for business" and the moral claims of private life. But what is this "rule for business?"

The answer, in short, is that certain moral responsibilities come with certain social roles. The job of being a military officer, a nurse, or an attorney brings particular obligations, as does the job of running a business. The chairman of Roussel UCLAF, Edouard Sakiz, decided at one point to overrule his strong, personal convictions and oppose the marketing of RU 486. Sakiz feared that protests and boycotts by anti-abortion groups would 
do too much damage to Roussel and Hoechst, saying "We have a responsibility in managing a company. But if I were a lone scientist, I would have acted differently."

Why couldn't Sakiz act on the basis of his personal values and commitments in life? The reason is that, as a business executive, Sakiz had to take account of other compelling responsibilities.

The Commitments of Economic Agents-Some of these responsibilities arose from a second sphere of moral claims, which derived from Sakiz's role as an economic agent. These obligations are familiar territory for American managers. Their job, as economists, corporate attorneys, and their superiors often remind them, is to serve the interests of shareholders. What is realized less often is that this is not just a legal and practical obligation but also the most visible and familiar element in a sphere of responsibilities that are deeply moral in character.

The ties between the owners of a company and the managers who act as their agents are inescapably moral. Shareholders entrust their assets to managers, and managers promise, implicitly or explicitly, to work for the shareholders' interests. Like any promise, this relationship of trust carries strong moral weight. Moreover, this obligation is reenforced by the duty that all citizens have to obey the law. In an overview of executives' legal obligations, Robert Clark, the Dean of the Harvard Law School, wrote: "Case law on managers' fiduciary duty of care can fairly be read to say that the manager has an affirmative, open-ended duty to maximize the beneficiaries' wealth, regardless of whether this is specified in any actual contract." ${ }^{5}$ Of course, this obligation does not always trump all other moral claims, and difficulties arises when fiduciary obligations clash with other moral interests. Nevertheless, the laws obligating managers to serve shareholders' interests are woven deeply into the legal fabric of commercial life in the United States and many other countries. These laws reflect the preferences and considered judgements of societies; they have been enacted by legitimate government bodies; hence, they create strong moral claims on business executives.

The economic responsibilities of executives do not arise solely from duties to keep promises and obey the law. Consequences also matter. Society benefits when managers and companies compete vigorously to serve owners' interests. Much of the wealth flowing from the capitalist cornucopia directly alleviates human suffering and provides pleasure, security, health, and prosperity for many members of society. These consequences are a moral achievement, not simply a material or economic one. The British philosopher John Stuart Mill concluded that good actions-that is, morally good actions - are those that bring the greatest happiness to the greatest number. Indeed, Mill asked what else morality could be about, if it 
were not fundamentally a matter of promoting happiness and alleviating suffering. Does capitalism accomplish this? The economist Joseph Schumpeter gave this answer: "Verification is easy. There are no doubt some things available to the modern workman that Louis XIV himself would have been delighted to have-modern dentistry for instance . . . the capitalist process, not by coincidence but by virtue of its mechanism, progressively raises the standard of life of the masses." ${ }^{.6}$ Capitalism, in short, provides the material base for the lives, happiness, and welfare of many people.

Market systems, moreover, achieve these moral ends in moral ways. Individuals choose the work they wish to do, the products and services they wish to buy, and the ways they invest their savings. Vigorous competition expands the range of choices in the markets for labor, capital, and goods. When people make these choices, they are exercising their rights as autonomous individuals. Market transactions are, in Robert Nozick's phrase, "capitalist acts between consenting adults." Of course, actual capitalist systems fall far short of these ideals-because of class interests, power politics, disparities in income and wealth, and the political influence of corporations and other groups. Nevertheless, market systems rest upon bedrock moral beliefs about the autonomy of individuals, the value of freedom and consent, and the centuries-long struggle to free individuals from the power of the state and the church. The Boston Tea Party was at once a commercial and a political act, and it is no accident that the nations of Eastern Europe are simultaneously embracing capitalism and democracy. To be sure, serious problems co-exist with market systems and are often exacerbated by them, and the failures and limits of capitalist economies have been well chronicled. But to acknowledge that markets fail is not to deny their basic moral traits: providing the material base for the happiness of many people and widening the range of ways of choices open to them.

It would be natural to think that the moral dilemmas of management arise when economic duties conflict with executives' personal values and convictions. But two other spheres of responsibility also make strong claims on managers and make these dilemmas even more complex. Both of these other spheres share the same origin: the fact that modern economies do not fit the Adam Smith picture of tiny economic units banging against each other like billiard balls in competitive markets. This view presupposes that firms and their managers have little power, a condition that holds mainly in theory. Under conditions of pure competition, firms are price-takers, and when a company innovates and earns exceptional profits, competitors rush in, drive prices down, and take from the innovator the market power that its breakthrough gave it. In actuality, however, firms and their managers often wield enormous economic, political, and social power. With this power, come other responsibilities. 
Commitments as Company Leaders-Another sphere of responsibility exists because employees and managers are members of semi-permanent human communities, conventionally called companies. This new form of social organization emerged roughly a hundred years ago, when the entrepreneurial capitalism of small-scale business gave way in many industries to managerial capitalism. This was a development that the classical economists had not thought about or perhaps even imagined. In the 600 pages of The Wealth of Nations, Adam Smith treats firms only in a few passing references to tiny operations like apothecaries, collieries, and farms. However, within a century of Smith's death, giant firms, exploiting economies of scale and scope, came to dominate much of the economic landscape. They employed thousands or tens of thousands of people, as workers and managers, on a long-term basis. Some were larger than countries. In the mid-1960s, for example, General Motors' sales exceeded the gross national products of all but four countries, and despite its recent woes, General Motors has now survived longer than the Soviet Union.

A Japanese scholar has described firms in his own country as "capsules." Such firms are semi-closed societies, communal groups that enlist the loyalty and trust of employees and envelop much of their lives. ${ }^{8}$ Indeed, the word "employee" is misleading. People become members of these business organizations, they devote much of their life's energy to their work, and their lives and livelihoods are deeply bound up in the firms' activities. This phenomenon, of course, is hardly unique to Japan. Consider an episode at Levi Strauss, a leading apparel maker, just a few years ago. The company had made substantial efforts to protect the rights of people with HIV and AIDS and help them continue working when they were ill. One man with AIDS said, "It was so important for me to come to work and get away from all the pain - the company was the environment that helped me keep my self-respect." Later, when this man died, one of his co-workers said "I shed tears for him and for the great friend I had lost."

What does this vignette suggest? First, that work is a powerful source of meaning and value-in this case, self-respect-in individuals' lives. Many people realize some of their deepest aspirations - for security, for a sense of belonging, contribution, and achievement-on the job. The co-worker's comment also reminds us how workplaces can nurture deep loyalties, strong friendships, and abiding ties among individuals. People live much of their lives at work, rather than in neighborhoods, religious and political groups, or even at home with families. Finally, the episode reveals managers' power: as business executives lead, guide, and shape these large, semipermanent social and economic communities, they exert enormous power over the lives and welfare of many other human beings.

The power that executives exercise over the lives of others leads to two strong moral claims. The first is the obligation not to abuse this power. Consider, for a moment, how great the force of authority can be. In the 
early 1960s, a psychologist at Yale University performed a famous experiment in which volunteers from all walks of life were asked to help a researcher learn about the effects of punishment on memory. The learner, who was actually an accomplice of the experimenter, was strapped into a chair. The volunteers were told to give electrical shocks to the learner, depending on whether or not his answers were correct. (In actuality, no shocks were given-the subject was just acting.) Approximately $60 \%$ of the volunteers were extraordinarily obedient to authority: when the learner erred, the volunteers followed the directions of the experimenter and administered the highest levels of shock, even though the learner shouted, screamed, pleaded, and eventually fell silent. ${ }^{9}$

In some respects, situations in companies differ from this experiment. People often have time to reflect before acting, and they can talk about hard choices with friends, peers, and family members. Yet the "tools of management"- measurement and reward systems, culture, and the examples of peers and bosses-exert enormous, cumulative pressures on employees and managers. People often give in to organizational pressure to act unethically, or they stand on the sidelines while others do so. Responsibilities in organizations are often shared so no one feels personally and directly accountable. People say to themselves "It's not part of my job," or "It's the CEO's call and he runs the place," or "I have to pick my battles and this isn't the right one." The great twentieth century theologian Reinhold Niebuhr believed that individuals tended to behave less morally in groups than in their own private lives. Niebuhr wrote: "In every human group, there is less reason to guide and check impulses, less capacity for selftranscendence, less ability to comprehend the needs of others and therefore more unrestrained egoism than the individuals, who compose the group, reveal in their personal relationships." ${ }^{10}$

Power begets responsibility. Hence, business executives must exercise their stewardship over company communities in ways that meet a basic threshold of decency and respect for the rights and dignity of employees and managers. But this duty merely sets a base level of responsibility: it says only "do no harm" and ignores the enduring commitments that motivate executives' work. For these men and women, work is the stage upon which they live out many of their hopes and fears, seek identity and purpose, and gain the sense of achievement and self-worth that undergirds their lives. Their ideals and aspirations take different forms but nearly all are variations on the same themes: many executives want to build companies that are independent, strong, growing, and vital; that attract and keep top-quality talent; that are challenging and rewarding places to work; that provide opportunities for employees to grow and develop; that will survive hostile, uncertain competitive environments, and will endure and prosper for decades. Some executives have even broader aspirations. Steve Job's mission for Apple Computer was "to make a contribution to this world 
by making tools for the mind that advance humankind." Merck's corporate purpose is "preserving and improving human life."

Many men and women commit much of their lives and energy to creating such companies. And while companies must serve shareholders' interests, neither their executives nor their employees leap from bed in the morning in order to maximize the risk-adjusted present value of streams of future cash flows. The animating, creative forces of great human institutions originate elsewhere. The men and women who build and guide enduring, productive, and challenging human communities are engaged in efforts which are not simply financial and administrative, but social, political, and moral. The political scientist James MacGregor Burns concluded that moral leadership arises when leaders and followers share needs, aspirations, and values. This is an aspect of successful companies that the widely touted notions of "family" and "team" try to capture. Not all companies and managers think in these terms; many, indeed, seem to subscribe to Woody Allen's observation that most of getting ahead in life is just showing up. But the many managers who are committed to higher aims are working within a distinctive, compelling sphere of moral responsibility.

Responsibilities Beyond Firm's Boundaries-It is natural to think that executives' responsibilities stop at their firms' boundaries. This supposes that companies are, in the words of one economist, islands of managerial coordination in a sea of market relations. " But this picture of the world is inaccurate and misleading. Many companies have complex relationships with government agencies, labor unions, or-through strategic allianceswith customers, suppliers, and even competitors. These firms resemble global networks and their boundaries are blurred.

This organizational reality creates a new and enormously complex sphere of responsibilities for managers. Again, the central issue is power. Just as business executives have enormous influence over the people "inside" their companies, they also have power over people and organizations that are "outside," but with which their operations and sometimes their destinies are intertwined. In Japan, West Germany, and other countries, groups of large and small firms are clustered in the form of cartels, keiretsu, and other confederations. America, despite its ideological preference for the Adam Smith model of small-firm competition, is home to many of the largest firms in the world, and they, too, are surrounded by vast cadres of suppliers and customers and often have close relationships with many government agencies.

Even when it is not part of a network of alliances, a firm's power extends beyond its boundaries. Through its products, the jobs it provides, the taxes it pays, and the business a firm gives its suppliers, a company influences, sometimes profoundly, the lives of many people. RU 486 provides a 
dramatic example. Its developers believed the drug could ultimately save tens of thousands of lives by providing another alternative to "coat hanger" abortions. Critics of RU 486 argued it would make abortion much easier, leading to more deaths of unborn children. RU 486 also seemed likely to change the politics of abortion: fewer abortions would take place in clinics, which were ready targets for protest, and abortions at the very start of a pregnancy seemed less likely to arouse political passions. In many other cases-less dramatic, but more commonplace than RU 486-a company's power and influence, and hence the responsibilities of its managers, also extend beyond the traditional boundaries of the firm. Pollution, unsafe products, and unfair competitive practices all injure other parties. And, when a company fails and shutters its factories, employees, their families, schools, local governments, and sometimes entire communities pay a price.

Obviously, managers cannot be held responsible for everything. Other groups in society - government bodies, labor unions, and consumershave significant responsibilities as well. In the case of RU 486, for example, government bodies were responsible for decisions on whether abortions were legal and whether particular drugs were safe and effective while physicians and women made choices among medical procedures. Sometimes, the law or widely accepted practices provide answers that are clear and morally sound, but in many cases the situation is more complex. Roussel UCLAF, for example, had to decide whether to make RU 486 available to the Chinese government. China wanted the drug for its population control program. The country's population was already 1.1 billion, and demographers had described the early 1990s as "the Himalayas of population growth" because 150 million Chinese women would soon reach their prime child-bearing years, and the government's decade-old "one couple, one child" policy seemed to have failed.

RU 486 might have helped China manage its population growth, but Roussel UCLAF had to consider how the drug might be used. In particular, would it be given to women under the strict medical supervision planned for France? Might women be forced to take RU 486, violating the "right to choose" that many company officials believed in? Given these uncertainties, how far did the company's responsibility extend? One could argue that they stopped at the "point of sale," that Chinese physicians and public officials then became accountable for the use or misuse of the drug. This viewpoint avoids the taint of cultural imperialism by respecting the rights and competence of the Chinese government. But suppose RU 486 was given improperly (too late in a pregnancy, for example) at several rural clinics in China and some women died, others were permanently injured, and some gave birth to handicapped children. Would the "point of sale" argument enable company executives wash their hands of responsibility? Would this way of thinking allay the guilt they might feel? And would the publicity and fear 
resulting from these tragedies impede the use of the drug in other countries, even under careful medical supervision? Company responsibilities do not cease at the point when a customer exchanges cash for goods. But where does the buck stop in a web of interdependent actors and shared responsibility?

Figure 1. Four Spheres of Commitments
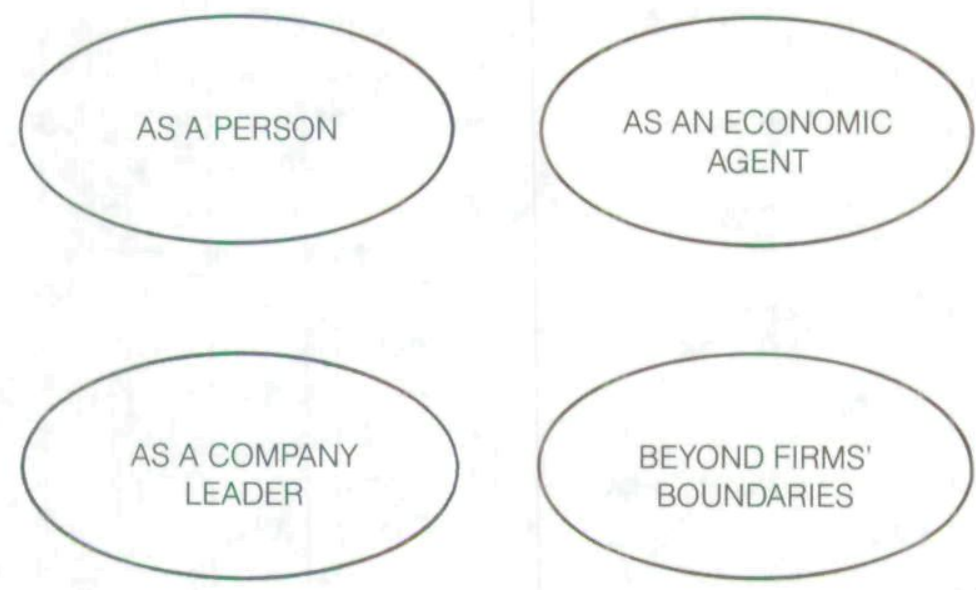

\section{Four Enduring Questions}

Moral claims arising from different spheres of responsibility often collide with each other, creating difficult, sometimes anguishing dilemmas for business executives. There is, unfortunately, no final, supreme principle for resolving conflicts of responsibility - not in the Bible or the Koran, nor in philosophy or theology books, not in the law, nor deep in the human heart, nor anywhere else. There is instead a long tradition of serious thought about power and responsibility that can help executives deal with conflicts among commitments and mitigate the problem of dirty hands. This tradition of thought is not a progression of ideas, culminating in some final conclusion, but a long, reflective conversation-spanning many generations, varied cultures, different social, political, and economic conditions, and the experiences and insights of many individuals.

Four questions represent important voices in this long conversation. Each encapsulates a fundamental idea about the responsibilities of men and women in positions of power. Moreover, each is closely associated with a handful of thinkers who used the question to crystallize the moral issues that confronted their societies at crucial moments in human history. Used 
together, the four questions provide a basic framework for assessing possible ways of resolving a difficult dilemma. The four questions are:

- Which course of action will do the most good and the least harm?

- Which alternative best serves others' rights, including shareholders' rights?

- What plan can I live with, which is consistent with the basic values and commitments of my company?

- Which course of action is feasible in the world as it is?

The first question - what will do the most good and the least harmfocuses on the morality of consequences. It is, in rough terms, John Stuart Mill's question. His basic view, called utilitarianism, is that morally good actions bring the best consequences for everyone they affect and do so with the least cost, risk, and harm. In the case of RU 486, the consequences were enormous: the survival of the Roussel UCLAF, the health and safety of millions of women who might use RU 486, the health of people with diseases the drug could treat, and the morality, politics, and regulation of abortion around the world.

Mill's question asks managers to examine the full range of consequences that will result from different ways of resolving a dilemma. The basic question must be broken into sub-questions: Which groups and individuals will benefit from different ways of resolving a dilemma? How greatly? Who will be put at risk or suffer? How severe will the suffering be? Can the risk and harm be alleviated? These questions, inevitably, serve as starting points of a process of fact-gathering and analysis; they are not a formula for reaching conclusions. There are no universal definitions of good or harm, nor are there any hard and fast ways of measuring and trading off harms and benefits against each other. Much depends upon particular circumstances, institutions, and legal and social arrangements. But the basic guiding question remains: Which course of action is likely to do the most good and the least harm?

The second question focuses on the morality of rights, an idea that crystallized in the seventeenth and eighteenth centuries. For Americans, the question is Thomas Jefferson's. His draft of the Declaration of Independence stated bluntly that human beings had inalienable rights to life, liberty, and the pursuit of happiness. We accept similar ideas in everyday life, believing that we and others have rights to be treated with respect, to have promises kept, to be told the truth, and to be spared unnecessary injury. Others have duties to respect these rights, particularly powerful individuals such as business executives. Hence, when executives consider various ways of resolving some dilemma, they must ask what rights are at stake. In the case of RU 486, this meant asking about the rights of women to have access to safer methods of abortion, about rights to safe medical procedures in countries with less developed medical infrastructures, and about the rights of the unborn. 
Like the question of consequences, the question of rights does not draw sharp boundaries around companies or around managers' responsibilities. The question asks about the rights of everyone affected by a decision. Both questions are the ethical counterparts of what many management analysts now call the borderless world: they look beyond the familiar boundaries of firm and nations, acknowledging Dr. Martin Luther King's insight that all people are bound together in a "seamless web of mutuality."

The third great force in moral thinking is captured in the third question. It asks: What course of action can I live with? What best serves my commitments and aspirations in life? And, for a business executive, this perspective asks: What course of action is most consistent with the kind of human community we are seeking to create? The roots of these questions lie in Aristotle's philosophy and in many religions. They ask executives who face difficult decisions to search their consciences, to regard their lives and aspirations as a whole, to ask, in effect, what they want to appear in their obituaries. This perspective also asks managers to think hard about what kind of human community their company is, and about the values that guide it and the purposes it solves. Inevitably, executives in wrenching situations, like that faced by the executives at Roussel UCLAF, will ask themselvesas they should - what course of action they can live with, as individuals and as leaders of a particular company.

The fourth question is Machiavelli's. It asks, purely pragmatically, what will work in the world as it is? In any situation, there may be several options that could, in theory, reconcile the competing claims. The crucial question then becomes: What is actually feasible - in view of a manager's actual power in an organization, a company's competitive, financial, and political strength, the likely costs and risks of various plans of action, and the time available for action?

For some people, this question is amoral or worse. It focuses on the means, not the ends, and it fails to examine the morality of the means. Moreover, Nicolo Machiavelli, the fifteenth-century Italian statesman and political philosopher, is widely considered an apologist for unscrupulous opportunism. But Machiavelli would not be remembered today for simply having argued the obvious: that unscrupulous people often get ahead. Machiavelli was a realist, preoccupied with "the necessities of power," with what leaders must do so their organizations can at least survive and perhaps prosper in the world that one finds, not the world one hopes for. Hence, morality must be practical. For people with real responsibility, meaning well is not good enough. A plan of action, however high-minded it may be, usually accomplishes little if it does not work. Moreover, Machiavelli's question was not a request for the cautious, satisficing action plans of the "organization man." He asked what will work if a leader is resourceful, persistent, imaginative, bold, and does not shun risk. 
Figure 2. Four Questions
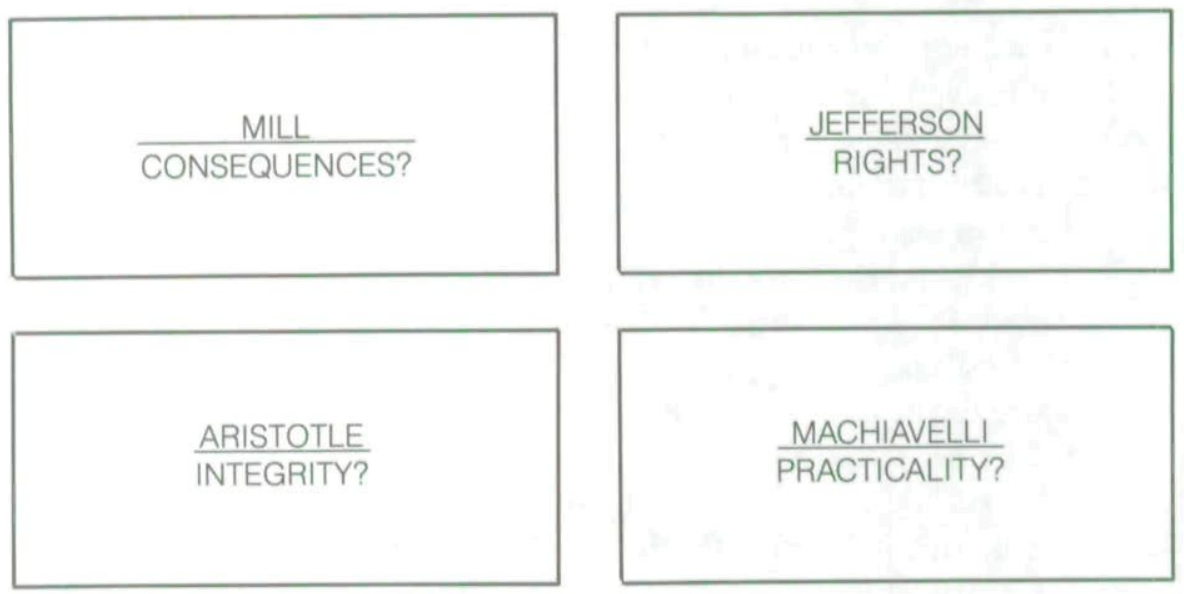

The four questions must be asked and answered together because, in crucial ways, they balance and correct each other. Enshrining any of them as "the answer" is dangerous. Machiavelli's question is a strong pull towards practicality, but as a sole perspective on difficult decisions it risks sleazy opportunism and needs to be balanced by the explicitly ethical concerns of the other three questions. Aristotle's question tries to root decisions in the abiding values of particular individuals and institutions; but this approach, by itself, can open the door to prejudiced, self-interested judgments.

In short, the moral dilemmas of management must be resolved through balancing acts - through decisions and actions that meet, as best they can, the conflicting claims of different spheres of responsibility. Edouard Sakiz's decision on RU 486 provides an instructive example. As mentioned earlier, Sakiz voted to suspend distribution of the drug. Five days later, Roussel UCLAF announced to the public that "pressure from anti-abortion groups" had led to this decision. The result was a firestorm of criticism-from women's groups, family planning organizations, and physicians in Europe and the United States. A few days later, the French Minister of Health told Roussel UCLAF that he would use his legal authority to transfer the RU 486 patent to another firm unless the company changed its decision. Roussel UCLAF quickly agreed to market the drug in France. After the Minister's decision, the company's vice-chairman said: "We are now relieved of the moral burden weighing on our company."

How successfully did Roussel and its managers meet their conflicting responsibilities? Sakiz and his fellow executives met their personal aspirations, as scientists and medical researchers, to introduce an alternative to 
surgical abortions, one that might someday reduce the number of women who would suffer and die from abortions, especially in poor countries. Their decision respected the rights of women, guaranteed by French law, to decide whether to seek an abortion, and it also acknowledged the right of the French government to play a role in a decision with potentially vast moral, social, and medical consequences. The rights of shareholders were served because a promising new product was brought to market, but in a fashion that might have diverted protests and boycotts away from Roussel UCLAF and its parent since the French government made the final decision on marketing RU 486. Finally, the company sought to achieve important consequences - principally reducing suffering and death-while seeking to minimize the negative repercussions for the firm, its executives, and Roussel UCLAF employees.

Yet this decision was an anguishing one for Sakiz and had the marks of a "dirty hands" dilemma. Roussel UCLAF would not be spared protests and boycotts; threats of violence would continue. Its executives were accused of shirking their responsibilities by letting the government make the final decision: a prominent scientist who contributed greatly to the development of RU 486 called the company's initial decision against distribution a "moral scandal." Some people even accused Sakiz of Machiavellian maneuvering, alleging that he and the Minister of Health had orchestrated the whole series of decisions about RU 486. Opponents of abortions, in Europe and the United States, continued to criticize Roussel UCLAF and its executives for killing unborn children.

In some situations, there is no win-win solution. Life does not come with a guarantee that good intentions, hard work, imagination, and farsightedness will turn all moral dilemmas into happy outcomes that satisfy the moral claims of all parties. The "best" way of resolving a dilemma may inevitably involve some violation of people's rights, it may bring harmful consequences, or it may severely test an executive's sense of integrity. Responsible, thoughtful, practical-minded people will often disagree on what is right in a particular situation. The four enduring questions posed above are not a formula for replacing judgement and are no guarantee against "dirty hands." They are, at best, an aid to judgment and a way to keep one's hands as clean as possible in the world as it is.

\section{References}

1. Chester Barnard, The Functions of the Executive (Cambridge, MA: Harvard University Press, 1982), p. 278.

2. Jean-Paul Sartre, Dirty Hands, in No Exit and Three Other Plays, translated by Lionel Abel (New York, NY: Vintage International, 1989), p. 218. The specific problem Sartre poses, the problem of "dirty hands" in public life, is analyzed in Michael Walzer, "Political Action: The Problem of Dirty Hands," Philosophy and Public Affairs (Winter 1973), pp. 160-180. 
3. I am using the notion of spheres in a way that is roughly analogous to that developed by the political philosopher Michael Walzer. His analysis of distributive justice is based upon a division of social life into different spheres of activities - each centered upon different goods - such as health or education. Walzer argues that the moral standards governing the distribution of each of these goods derive not from some grand, overarching theory of justice but rather from the particular meanings associated with a good in a particular community with a particular history. See Michael Walzer, Spheres of Justice (New York, NY: Basic Books, 1983), pp. 3-30.

4. Richard H. Tawney, Religion and the Rise of Capitalism (New York, NY: Harcourt, Brace and Company, 1926), p. 184.

5. Robert C. Clark, "Agency Costs Versus Fiduciary Duties," in John W. Pratt and Richard J. Zeckhauser, eds., Principals and Agents: The Structure of Business, (Boston, MA: Harvard Business School, 1985), pp. 71-79.

6. Joseph Schumpeter, Capitalism, Socialism, and Democracy, 3rd edition (New York, NY: Harper Colophon/Harper \& Row, 1975), pp. 67-68, 83.

7. Robert Nozick, Anarchy, State and Utopia (New York, NY: Basic Books, Inc., 1974), p. 163.

8. See Moriaki Tsuchiya, "The Japanese Firm as a Capsule," Japanese Economic Studies (Fall 1984), pp. 8-41.

9. See Stanley Milgram, Obedience to Authority (New York, NY: Harper and Row, 1974).

10. Reinhold Niebuhr, Moral Man and Immoral Society: A Study in Ethics and Politics (New York, NY: C. Scribner's Sons, 1932), p. xi.

11. G.B. Richardson, "The Organization of Industry," Economic Journal (October 1972), p. 883. 
Copyright of California Management Review is the property of California Management Review and its content may not be copied or emailed to multiple sites or posted to a listserv without the copyright holder's express written permission. However, users may print, download, or email articles for individual use. 